\title{
Work Line Balancing and Production Efficiency of Manufacturing Firms in Rivers State, Nigeria
}

\author{
Karibo Benaiah Bagshaw \\ Department of Management, Rivers State University, Port Harcourt, Nigeria \\ Email: bagshawkb@yahoo.com, bagshaw.karibo@rsu.edu.ng
}

How to cite this paper: Bagshaw, K.B. (2020) Work Line Balancing and Production Efficiency of Manufacturing Firms in Rivers State, Nigeria. American Journal of Industrial and Business Management, 10, 45-60. https://doi.org/10.4236/ajibm.2020.101004

Received: November 20, 2019

Accepted: January 6, 2020

Published: January 9, 2020

Copyright $\odot 2020$ by author(s) and Scientific Research Publishing Inc. This work is licensed under the Creative Commons Attribution International License (CC BY 4.0).

http://creativecommons.org/licenses/by/4.0/

\begin{abstract}
Manufacturing firms are faced with the sequencing of tasks in workstations as the capabilities of manufacturing firms is to harness resources through the effective sequencing of task assignments in workstations. Thus, this study empirically examined work line balancing and production efficiency of manufacturing firms in Rivers State, Nigeria. Content on improving production efficiency by reducing non-value-added activities, cycle time and distribution of workload at each work station by work line balancing process, was also addressed. The dimensions of work line balancing were standardized work and one-piece flow; while production efficiency was measured using product output, product quality, and lead time reduction. The Pearson's Product Moment Correlation Coefficient (PPMCC) was used to test the significance of the relationship between dimensions of work line balancing and production efficiency. The findings showed that standard work procedures in work stations' task assignments provide better work line balance and show a positive significant relationship with product output and lead time reduction. Also, one-piece flow was revealed to have a more significant and positive relationship with product quality than product output and lead time reduction. Therefore, it was concluded that implementing appropriate work line balancing in the workstations should be an ongoing activity in the production process and setting capacity utilization baselines is key to improving production efficiency.
\end{abstract}

\section{Keywords}

Line Balancing, One Piece, Production Efficiency, Standardized Work

\section{Introduction}

In most manufacturing firms, it is imperative that workstation assignments are programmed in planning and scheduling available capacity to achieve output le- 
vels in meeting the objectives of capacity planning which are maximizing capacity utilization and maximizing market share [1] The schedule of work or task in the factory shows a timetable for performing activities using resources or allocating facilities [2]. The scheduling process is to disaggregate the master production schedule (MPS) into a time-frame activities period as necessary in the production process in meeting customers' orders. Demand for the firm's product comes mostly in product orders, which is an annexed function from marketing from varied periods and often accepted in uneven fluctuating quantities [3].

The firm in its capacity planning functions will supervise labour and machines in task assignment procedures that are expected to meet demand orders. The demand can be accepted as customers' orders collected for all demand in one month; and two weeks of safety stock. The assignment of tasks to machines follows vital rules depending on data such as processing time, due date and other seemingly relevant rules in determining which jobs are sequenced first in the workstations. It is likely that manufacturing firms in the awareness of balancing the work line in workstations need to achieve the objectives of production efficiency in measures of maximizing capacity utilization, maximizing product output, product quality, lead-time reduction and minimizing the total flow time. These measures used in assessing the workstations' operations create a gap in the smoothness of the production process in the scheduling of jobs to machines.

The jobs are assigned to the workstations and the decisions in the assignment procedure depend on the operations and routing requirements of each job, status of existing jobs on the machines, the queuing of work before each machine, job priorities, material availability, anticipated job orders, and worker and machine capabilities [2]. The need for manufacturing firms to adopt the work line balancing technique has become imperative to optimize the workstation as well as reduce the production time and maximizing output. Originally, work line balancing was developed for a cost-efficient mass production of standardized products, designed to exploit a high specialization of labour and the associated learning effects. Also, when work line balancing is been used this makes efficient flow line systems available for low volume assembly order production and enables modern production strategies like mass customization. It maximizes the division of labour, thereby maximizing system productivity [4]. Therefore, the configuration of the work line and the distribution of work along the line are fundamental to the production system's efficiency.

Production efficiency is a term used to describe the state or level at which a manufacturing firm is producing the greatest number of units while utilizing the least amount of resources possible [5]. The idea is to achieve a balance of task assignments in the work stations as not to overload or under-load a given work station. Evaluating production efficiency typically involves assessing each phase of the production process. The assessment begins with the acquisition of raw materials and continues through the consumption of those materials as new products are assembled and completed. 
The need for balancing the work line becomes obvious when it is considered that the output to be received from the line is determined by the maximum time involved in the performance of work at one particular workstation. The imbalances existing in the work line would lead to wastage of time at all other work stations; thus, an efficient balance among the activities will complete the required work while maintaining the specified sequence and minimizing the idle time [6].

\section{Statement of the Problem}

The need for balancing the work line becomes obvious when it is considered that the output to be received from the line is determined by the maximum time involved in the performance of work at one particular workstation. The imbalances existing in the work line would lead to wastage of time at all other work stations; thus an efficient balance among the activities will complete the required work while maintaining the specified sequence and minimizing the idle time [6]. The production line of manufacturing firms in Rivers State, Nigeria was observed to be experiencing technical problems of high idle time, high labour cost and low line efficiency. Therefore, the purpose of the study was to empirically examine work line balancing and production efficiency of manufacturing firms in Rivers State, Nigeria.

\section{Literature Review}

\subsection{The Concept of Work Line Balancing}

The concept of line balancing can simply be seen as the allocation of sequential work activities into a line called work stations to achieve the best utilization of labour and equipment thus minimizing idle time. In addition, work line balancing can be realized by the structuring of task assignments and sequencing jobs in the work stations based on equalizing workload among the work stations avoiding neither over-load nor under-load as to have smooth and even operations within the same cycle time. Furthermore, line balancing benefits an assembly area in many ways, as it minimizes the number of workers and work station which can reduce cost and space for the assembly area. Line balancing also benefits in a way that it can identify the process which causes bottleneck and standardization of work between the operators can ease the bottleneck problem [7].

Work Line balancing is all about arranging a production line so that there is an even flow of production from one work station to the next. Work Line balancing is also a successful tool to reduce bottleneck by balancing the task time of each work station so that there are no delays and nobody is overburden with their task. According to Falkenauer (2009) [8] work Line balancing, is the problem of assigning operations to workstations along a work line, in such a way that the assignment is optimal in some sense. Furthermore, Work line balancing can also be defined as systems which are formed by arranging workstations along a line. Work pieces at the work stations can be moved using labour or equipment, 
with connected tasks taken sequentially bearing in mind possible constraints in the precedence relationship of tasks within the production cycle time. Work line balancing methods attempt to allocate equal amounts of time for each worker so that the production flows smoothly without long waiting times [9].

Liu and Chen (2002) [10] presented a generic algorithm approach for work line balancing planning involving various objectives, such as minimizing cycle time, maximizing workload smoothness, minimizing the frequency of tool change, minimizing the number of tools and machines used and minimizing the complexity of assembly sequences. The traditional methods of work line balancing assumed that production task time is constant, which is not realistic [11]. In labour intensive production processes like the agro-industry, the task time is uncertain since it depends on the skill of each employee, work environment, fatigue [7] [12]. The main objective of line balancing is to distribute the task evenly over the work station and line balancing aims at grouping the tasks or job floor workers in an efficient pattern to obtain the most efficient balance of the capacities and flow of the assembly processes.

\subsection{Dimensions of Work Line Balancing}

\subsubsection{Standardized Work}

According to Boyer (2008) [13] standardized work was opined to be a document centred on human actions that combines the elements of a job to do in an effective sequence, without waste, to achieve the most efficient level of production. Standardized work is a distinct framework which includes three critical elements: task time, standard work, and job sequence. The most critical factor in applying standardized work is to consistently train the workforce in handling machines especially technological driven machines that increases work process efficiency. This creates awareness and understanding among employees as they know what to do and how to do the job. By documenting the current best practice in task or job performance, standardized work forms the baseline for continuous improvement. Given improvements to the work standard, the new work standard is considered as baseline for subsequent developments or enhancements of work. In this way, the improvements to standardized work can be viewed as an ongoing process which allows for and embraces a culture of innovation.

Standardization of work processes is needed to facilitate efficient, safe work methods and eliminate wastes, while maintaining quality [14]. Standardizing the work adds discipline to the work culture, an element that is frequently neglected but essential for lean production practice. Standardized work allows the work instructions of current processes themselves covering all processes, all employees and all shifts, therefore, reducing variation, and making training much easier. The features of standardizing include safe systems of work, quality assurance, and control, the movement of employee process elements to organizational documented process elements, providing the benchmark or baseline for all future 
improvement.

\subsubsection{One Piece Flow}

One-piece flow (also commonly referred to as continuous flow manufacturing) is a technique used to manufacture components in a cellular environment. The goals of one-piece flow are to make one part at a time correctly all the time to eliminate unplanned interruptions and lengthy queue times [15]. The one-piece flow explains the steps of either product manufacturing or the transactional activities of a product, in producing a unit at a time. On the other hand, the batch production system creates a large number of job units sending them together as a group through each operational stage or phase. The focus of the one-piece flow is on the processes associated with the product or transactional activities and not on the waiting, storage and transportation of such products.

There are many advantages to incorporating the one-piece flow method into work processes. One-piece flow plays a key role in reducing the time that elapses between a customer order and shipment of the finished product. One-piece flow also helps in preventing the waiting times and production delays that can occur during batch processing. By reducing excess inventory, one-piece flow reduces the labour, energy, and space that employees must devote to storing and transporting batch lot sizes. One-piece flow gives an organization the flexibility to meet customer demands for a specific product at a specific time; and reduces operating costs by making non-value-added work more evident [16].

\subsection{Measures of Production Efficiency}

\subsubsection{Product Output}

Product Output is commonly defined as a ratio of a volume measure of output to a volume measure of input use. Product output can also be defined as the result of any tangible or intangible goods produced by a firm [17]. Different methodologies to obtain quantity series of product output can significantly shape the outcome of productivity measurement.

\subsubsection{Product Quality}

Crosby defines product quality as the producer's ability to meet expectations (Crosby, 1979 quoted in Parasuraman, Zeithaml \& Berry, 1985) [18]. As far as the customer's (consumer's) point of view is concerned, quality can be defined as the quality perceived upon the basis of the consumer's decision on the overall excellence or superiority of the product [19]. Again, product quality is the degree to which satisfaction is met by inherent elements in the product [20]. It is the intrinsic properties in the product that gives satisfaction to the consumer.

Garvin (2007) [21] explicated that product quality is primarily seen as conformance to customer's demand specifications and expectations. Product quality can be seen as subjectively perceived by customers. Therefore, the main measure of product quality is customer satisfaction. To achieve high customer satisfaction, it is crucial for manufacturing firms to produce products that fulfil the customers' requirement [22]. 


\subsubsection{Lead Time Reduction}

In the competitive business environment, manufacturing firms are expected to achieve small lead times, low costs and high customer service levels. Lead time reduction can be defined as the time spent between the original customer order and final delivery of the product [23]. Nielsen, Michna \& Do (2014) [24] defined lead time as the time spent that elapses between the placement of an order and the receipt of the order into inventory and that the lead time may influence customer service and impact inventory costs. In an attempt to reduce lead time, manufacturing firms and organizations found that in reality $90 \%$ of the existing activities are non-essential and could be eliminated.

Harrington, (1996) [25] proposes by eliminating the non-value adding activities from the processes and streamlining the workflow resulting in significant optimization of the throughput time in the work stations process line balancing. Balancing the work line focused on processes eliminates waste associated with changeovers, quality defects, process control, factory layout, and machine downtime. It is acceptable therefore in today's competitive business environment, manufacturing firms need to be able to have task assignments in balanced workflow to achieve shorten the throughput time, increase in production output and minimizing lead time.

\section{Methodology}

The design chosen for the study is the survey research design. This choice is based on the noted suitability and effectiveness of the survey design is addressing phenomena which can be categorized as social or organization-based given its capacity for convenience and low interference in data generation from a broad range of cases [26]. The study population comprised of 44 manufacturing firms sourced from the directory of the Manufacturers' Association of Nigeria (MAN) in the Rivers/Bayelsa State chapter, Nigeria. The unit for measurement in the study was fixed at the managerial level, as such instruments were administered to 4 key managers within each organization noted to occupy strategic positions related to production and operations of the manufacturing firms, bringing the number of questionnaires distributed to 176 respondents. The strategic positions are Operations managers, Production managers, Operations supervisors and Assembly (work line) supervisors.

\section{Data Analysis}

The tests for hypotheses were carried out using 0.05 level of significance, implying significance at a $\mathrm{P}<0.05$ and insignificance at a $\mathrm{P}>0.05$. The decision rule is to accept the null hypothesis if the $\mathrm{t}$-calculated is less than $(<)$ the $\mathrm{t}$-tabulated $=$ 1.96 for a 2 -tailed test at 0.05 significant level.

\subsection{Test of Hypothesis 1}

$\mathrm{HO}_{1}$ : There is no significant relationship between standardized work and product output. 
Table 1 showed the analysis of the relationship between standardized work and product output and the correlation coefficient $r=0.972$. This indicates that a very strong positive relationship exists between standardized work and product output. The probability/significant value $(\mathrm{PV})=0.000<0.05$ (level of significance); therefore, the null hypothesis is rejected and that there is a significant positive relationship between standardized work and product output. This implies that a manufacturing firm improvement on standardized work will also bring about an improvement in product output.

\subsection{Test of Hypothesis 2}

$\mathrm{HO}_{2}$ : There is no significant relationship between standardized work and product quality.

Table 2 showed the analysis of the relationship between standardized work and product quality and the correlation coefficient $(r)=0.848$. This indicates that a very strong positive relationship exists between standardized work and product quality. The probability/significant value $(\mathrm{PV})=0.000<0.05$ (level of significance); therefore, the null hypothesis is rejected and that there is a significant positive relationship between standardized work and product quality. This implies that as manufacturing firms improve on standardized work, will bring about an improvement in product quality.

\subsection{Test of Hypothesis 3}

$\mathrm{HO}_{3}$ : There is no significant relationship between standardized work and lead time reduction.

Table 3 showed the analysis of the relationship between standardized work and lead time reduction and the correlation coefficient $(r)=0.947$. This indicates that a very strong positive relationship exists between standardized work and lead time reduction. The probability/significant value $(\mathrm{PV})=0.000<0.05$ (level of significance); therefore, the null hypothesis is rejected and that there is a significant positive relationship between standardized work and lead time reduction. This implies that an increase in standardized work will also bring about an increase in lead time reduction.

\subsection{Test of Hypothesis 4}

$\mathrm{HO}_{4}$ : There is no significant relationship between one-piece flow and product output.

Table 4 showed the analysis of the relationship between one-piece flow and product output and the correlation coefficient $(r)=0.820$. This indicates that a very strong positive relationship exists between one-piece flow and product output. The probability/significant value $(\mathrm{PV})=0.000<0.05$ (level of significance); therefore, the null hypothesis is rejected and that there is a significant positive relationship between one-piece flow and product output. This means that a reduction or increase in one-piece flow will also bring about a reduction or increase in product output. 
Table 1. Correlation analysis showing the relationship between standardized work and product output.

\begin{tabular}{cccc}
\hline & & Standardized Work & Product Output \\
\hline Standardized Work & Correlation Coefficient & 1.000 & $0.972^{* *}$ \\
& Sig. (2-tailed) & - & 0.000 \\
Product Output & $\mathrm{N}$ & 176 & 176 \\
\hline & Correlation Coefficient & $0.972^{* *}$ & 1.000 \\
& Sig. (2-tailed) & 0.000 & - \\
\hline
\end{tabular}

Source: Survey Data, 2019.

Table 2. Correlation analysis showing the relationship between standardized work and product quality.

\begin{tabular}{cccc}
\hline & & Standardized Work & Product Quality \\
\hline Standardized Work & Correlation Coefficient & 1.000 & $0.848^{* *}$ \\
& Sig. (2-tailed) & - & 0.000 \\
Product Quality & Correlation Coefficient & 176 & 176 \\
\hline Sig. (2-tailed) & $\mathrm{N}$ & $0.848^{* *}$ & 1.000 \\
& N & 176 & 176
\end{tabular}

Source: Survey Data, 2019.

Table 3. Correlation analysis showing the relationship between standardized work and lead time reduction.

\begin{tabular}{cccc}
\hline & & Standardized Work & Lead Time Reduction \\
\hline & Correlation Coefficient & 1.000 & $0.947^{* *}$ \\
Standardized Work & Sig. (2-tailed) & - & 0.000 \\
& $\mathrm{~N}$ & 176 & 176 \\
\hline \multirow{2}{*}{ Lead Time Reduction } & Correlation Coefficient & $0.947^{* *}$ & 1.000 \\
& Sig. (2-tailed) & 0.000 & - \\
\hline
\end{tabular}

Source: Survey Data, 2019.

Table 4. Correlations analysis showing the relationship between one-piece flow and product output.

\begin{tabular}{cccc}
\hline & & One Piece Flow & Product Output \\
\hline One Piece Flow & Correlation Coefficient & 1.000 & $0.820^{* *}$ \\
& Sig. (2-tailed) & - & 0.000 \\
N & Correlation Coefficient & 176 & 176 \\
\hline Sne Piece Flow & Sig. (2-tailed) & $0.820^{* *}$ & 1.000 \\
& $\mathrm{~N}$ & 0.000 & - \\
& & 176 & 176
\end{tabular}

Source: Survey Data, 2019. 


\subsection{Test of Hypothesis 5}

$\mathrm{H}_{5}$ : There is no significant relationship between one-piece flow and product quality.

Table 5 showed the analysis of the relationship between one-piece flow and product quality and the correlation coefficient $(r)=0.944$. This indicates that a very strong positive relationship exists between one-piece flow and product quality. The probability/significant value $(\mathrm{PV})=0.000<0.05$ (level of significance); therefore, the null hypothesis is rejected and that there is a significant positive relationship between one-piece flow and product quality. This implies that an improvement in one-piece flow will also bring about an improvement in product quality.

\subsection{Test of Hypothesis 6}

$\mathrm{HO}_{6}$ : There is no significant relationship between one-piece flow and lead time reduction.

Table 6 showed that the correlation coefficient $(r)=0.874$. This indicates that a very strong positive relationship exists between one-piece flow and lead time reduction; which implies that an improvement in one-piece flow will also bring about an improvement in lead time reduction. The probability/significant value $(\mathrm{PV})=0.000<0.05$ (level of significance) therefore a significant relationship exists between one-piece flow and lead time reduction.

Table 5. Correlations Analysis showing the relationship between one-piece flow and product quality.

\begin{tabular}{lccc}
\hline & & One Piece Flow & Product Quality \\
\hline \multirow{3}{*}{ One Piece Flow } & Correlation Coefficient & 1.000 & $0.944^{* *}$ \\
& Sig. (2-tailed) & - & 0.000 \\
& N & 176 & 176 \\
Product Quality & Correlation Coefficient & $0.944^{* *}$ & 1.000 \\
& Sig. (2-tailed) & 0.000 & - \\
& $\mathrm{N}$ & 176 & 176 \\
\hline
\end{tabular}

Source: Survey Data, 2019.

Table 6. Correlations Analysis showing the relationship between one-piece flow and lead time reduction.

\begin{tabular}{cccc}
\hline & & One Piece Flow & Lead time Reduction \\
\hline \multirow{2}{*}{ One Piece Flow } & Correlation Coefficient & 1.000 & $0.874^{* *}$ \\
& Sig. (2-tailed) & - & 0.000 \\
\hline \multirow{2}{*}{ Lead Time Reduction } & N & 176 & 176 \\
& Correlation Coefficient & $0.874^{* *}$ & 1.000 \\
& Sig. (2-tailed) & 0.000 & - \\
\hline
\end{tabular}

Source: Survey Data, 2019. 


\section{Discussion of the Findings}

\subsection{Standardized Work Contributes Significantly towards Product Output}

This finding agrees with Zupan and Herakovic (2015) [27] position that standardized work affects product output. Also, Jackson and Schuler (1985) [28] affirmed that standardized work has been found to have a relationship with product output. Establishing standardized work and Product output relies on collecting and recording data on a few forms. These forms are used by production manager and manufacturing frontline supervisors to design the process and by the operators to make improvements in their jobs. Standardized operations and production output are the backbone of continuous improvement (Kaizen) systems. Standardized work is the documentation of the process. Standardized work processes as baseline work procedures from which continuous work improvement are carried out.

\subsection{Standardized Work Significantly Enhances Product Quality}

Emiliani (2008) [29] presented the practical framework for implementing standardized work and product quality which is created in relation to the strategic and day-to-day tasks of executive leadership by providing a new definition of leadership, a precise description of business principles, and a standard skill set for executives. Zupan and Herakovic (2015) [27] also observed that in the absence of a standard working pattern, the quality of the outputs tend to vary to the extent of the irregularity in the production method.

Standardization of work processes is needed to facilitate efficient, safe work methods and eliminate wastes while maintaining product quality [14]. Emiliani (2008) [29] presented the practical framework for implementing standardized work and product quality which is created in relation to the strategic and day-today tasks assignments in the work stations by providing a precise description of necessary tasks to balance the process line. Standardized work tends to enhance the chances and possibility of all activities being carried out safely. Effective work standards focus on safety, and unsafe work practices are appropriately removed from the process line.

The use of standardized work principles is a very effective method to methodically organize work elements, and efficiently establish employee movements within a work area. Employees are involved with the elimination of waste, producing high-quality products while working safely and need to identify and implement continuous improvements. The quality of the job is controlled with standardized work by eliminating variation in the task that is being done. The quality of the product is usually improved because there will be less human variation with people working and following the documented work sequences or routines as effectual in standardized work.

\subsection{Standardized Work Has a Significant and Positive Relationship with Lead Time Reduction}

This finding reiterates the views of Galinsky, Bond, Kim, Backon, Brownfield 
and Sakai (2005) [30] in their observation that the satisfaction of the employees is adversely affected when they are overloaded with tasks because they are become prone to making mistakes because they feel angry towards their employer and resentful to co-workers. Also, Boyer (2008) [13] pointed out that Standardized work is a distinct framework which includes three critical elements: Task time, standard work, and job sequence. The most critical factor in applying standardized work is to impart training to the workforce. This creates awareness and understanding among employees as they know what to do and how to do the job; this helps in reducing time spent in a particular work process. Manufacturing firms need to gain an understanding of the continuous improvement process, and the importance of waste elimination in the long-term growth of their business [31].

Standardized work and lead time reduction practice is one of the several practices utilized by manufacturing firms to integrate employees in the continuous improvement process. Employee must understand why standardized work and lead time reduction is important, and the linking of standardized work to continuous improvement. Manufacturing firms and employees need to understand this philosophy, utilize the standardized work development and lead time reduction process, and realize production efficiency. The ability to deliver sooner will win businesses away from competitors with similar product features, quality, and price. Again, quick delivery dates can justify a premium price and will certainly enhance customer satisfaction. Shorter lead time increases flexibility, reduces the need for inventory buffers and lowers obsolescence risk [17].

\subsection{One-Piece Flow Contributes Significantly towards Product Output}

This finding is supported by the views of Askin and Goldberg (2010) [15] in his observation that as a technique used to manufacture components in a cellular environment. The goals of one-piece flow are to make one part at a time correctly all the time to achieve this without unplanned interruptions and without lengthy queue times and consequently, increase output per time. Within Product output, one-piece flow is a key concept since value stream can be transformed into a one-piece flow operation. Product output emphasises workflow, focusing on customer value, and improving business. One-piece flow helps organizations accomplish these goals by reducing work expenses and eliminating waste.

One-piece flow describes the sequence of product or transactional activities through a process one unit at a time. In contrast, batch processing creates a large number of products or works on a large number of transactions at one time sending them together as a group through each operational step. In one-piece flow, focus is on the product or the transactional process, rather than on the waiting, transporting, and storage of either. One-piece flow methods need short changeover times and are conducive to a pull system [16]. 


\subsection{One-Piece Flow Significantly Enhances Product Quality}

According to George \& Zhou (2002) [32], one-piece flow significantly relates to the quality of products by production firms. In one-piece flow, focus is on the product or the transactional process, rather than on the waiting, transporting, and storage of either. One-piece flow methods need short changeover times and are conducive to a pull system. One-Piece Flow is a fundamental and important element of improving product quality. It should be related to the customers' requirements and it does mean that manufacturing firms should only process what the customer wants, in the required quantity to deliver the product at a given due date.

One-piece flow and product quality describes the sequence of product or transactional activities through a process one unit at a time. In contrast, batch processing creates a large number of products or works on a large number of transactions at one time sending them together as a group through each operational step [16] [33]. One-piece-flow also highlights problems with vendors which issues concern delivery dates and product quality. The one-piece flow makes it easier to observe bottlenecks and fixes the flow which leads to future gains in the workflow.

Above all, one-piece-flow is the key to quality improvements [34]. It is pretty common to get a better gain in quality once you are in a one-piece-flow. This occurs naturally as work line balancing ensures that quality is built into the product at every work station in the line as opposed to trying to inspect quality at the end (never pass a defect down the line). Using one-piece flow makes has a higher propensity that products will be of better quality than products from mass production. This is because errors are more likely to be spotted easily through the process than at the very end when it's too late to correct them.

One-piece flow builds in product quality. When we "make one, move one" defects are detected immediately (usually the next work station) forcing immediate corrective action; while, in batch production defects are difficult to eliminate when observed or identified downstream the production line. One-piece flow and product quality helps to reduce inventory as with one-piece flow, work in process (WIP) is reduced. Also, many of the wastes so inherent with batch and queue production (motion, transportation, and waiting) are greatly reduced with one-piece flow. As a result, product output with fewer defects increases and allows for shorter delivery dates.

\subsection{One-Piece Flow Has a Significant and Positive Relationship with Lead Time Reduction}

This finding is supported by Kuhlang (2011) [35] discovered that lead times for production are affected by factors like capacity, loading, batching and scheduling. In turn, the lead times affect factors like cost and control. This is as Tang \& Chang (2010) [36] revealed that when an employee has two or more job requirement, it becomes unclear as to know which to do first. In achieving one-piece 
flow and lead time reduction, the production process in the work stations would have experienced work line balance resulting in reductions in manufacturing throughput time; increase flexibility and reduce the time required to respond to customer orders. This can be vital to the survival and profitability of numerous manufacturing firms, especially those experiencing increased market pressures for shorter delivery lead times of customized product. In other words, shorter lead time increases flexibility, reduces the need for inventory buffers and lowers obsolescence risk.

The lead times for production are affected by factors like capacity, loading, batching and scheduling. A product flow (one-piece flow) with shorter lead times has a higher output and increases the value added to the product within a certain time. The objective for the processes is to perform the value-added work within the shortest possible time to reduce the process time, transportation time and idle time; which cumulatively will result in a reduction of the lead time [4]. Reliable lead times are utterly important for the customers, allowing them to forecast their demand and make plans they can depend upon. These preconditions are difficult to live up to with make to order production. The planning and control of the make to order products are often complicated due to high variations in product range and process times. The complexity is further increased by unforeseen factors affecting the production like breakdowns, employee sick leave and delayed supply of raw material. Additionally, the customers place orders irregularly, causing an uneven demand on production capacity [3].

\section{Conclusions of the Study}

Work line balancing as an important tool has helped manufacturing firms in Rivers State, Nigeria solve the problem of imperfect allocation of work along various workstations. Assigning tasks to machines by right-sizing machine workload in the workstations, and having each process step notify the subsequent step of its current needs for materials, it would be possible to obtain low cost, better quality, and very rapid throughput times to respond to changing customer desires.

In summary by implementing standardized work concepts, manufacturing firms can achieve many potential benefits such as improved safety, increased productivity, and higher quality. In conclusion, standardized work and lead time reduction have in many ways helped to improve the manufacturing and production process. Qualities of jobs are controlled with standardized work by eliminating variation in the task that is being done [17]. The quality of the product is usually improved because there will be less human variation with people working and following the documented work sequences or routines.

Implementing one-piece flow is the first option in improving safety in the production floor because smaller amounts of product are moved at a time, which improves ergonomic conditions. Also, when with small lot sizes forklift carriers can be eliminated, with fewer chances for accidents. With the waiting time be- 
tween workstations reduced to zero, defects are found almost instantly; employees' productivity increases, because employees spend less time in traveling distances within the workspace transporting products, which leaves more time available for value-adding work.

\section{Conflicts of Interest}

The author declares no conflicts of interest regarding the publication of this paper.

\section{References}

[1] Chase, R. and Aquilano, N. (1985) Production and Operations Management. 4th Edition, Irwin, Homewood, 470-483, 533.

[2] Davies, R.C., Medbo, L., Engström, T. and Akselsson, R. (1999) Work and Work Place Design Using Empirical Shop Floor Information and Virtual Reality Techniques. http://www.ie.lth.se/IE/Roy/papers/IEA97/WorkplaceDesign.html

[3] Bagshaw, K.B. (2014) Assessing the Application of Production Scheduling; Demand Uncertainty and Performance of Manufacturing Firms in Rivers State, Nigeria. Journal of International Review of Management and Business Research, 3, 38-54.

[4] Amen (2000) An Exact Method for Cost Oriented Assembly Line Balancing. International Journal of Production Economics, 64, 187-195.

https://doi.org/10.1016/S0925-5273(99)00057-2

[5] Zielinski, J. and Czacherska, M. (2009) A Multiple-Rule Heuristic for Work Line Balancing. Journal of the Operational Research Society, 46, 62-69. https://doi.org/10.1057/jors.1995.7

[6] Becker, C. and Scholl, A. (2006) A Survey on Problems and Methods in Generalized Assembly Line Balancing. European Journal of Operational Research, 168, 694-715. https://doi.org/10.1016/j.ejor.2004.07.023

[7] Sane, S., Karandikar, V., Pulkurte, R. and Patil, S. (2014) Assembly Line Balancing: A Case Study in Silencer Manufacturing. International Journal of Current Engineering and Technology, 4, 15832-15336.

[8] Falkenauer, E. (2009) Branch-and-Bound Algorithms for the Multi-Product Assembly Line Balancing Problem. European Journal of Operations Research, 58, 215-222. https://doi.org/10.1016/0377-2217(92)90208-Q

[9] Bhattacharjee, T.K. and Sahu, S. (1988) A Heuristic Approach to General Assembly Line Balancing. International Journal of Operations and Production Management, 8, 67-77. https://doi.org/10.1108/eb054843

[10] Liu, C.M. and Chen, C.H. (2002) Multi-Section Electronic Assembly Line Balancing Problems: A Case Study. International Journal of Product Planning and Control, 12, 452-461. https://doi.org/10.1080/09537280210142781

[11] Das, B., Sanchez-Rivas, J., Garcia-Diaz, A. and. MacDonald, C. (2010) A Computer Simulation Approach to Evaluating Assembly Line Balancing with Variable Operation Times. Journal of Manufacturing Technology Management, 21, 872-887. https://doi.org/10.1108/17410381011077964

[12] Ongkunaruk and Wongsatit (2014) Multi-Objective Design of Team-Oriented Work Line Balancing. European Journal of Operational Research, 156, 326-352. https://doi.org/10.1016/S0377-2217(03)00054-7

[13] Boyer, D. (2008) A Weighted Approach for Work Line Balancing Design with Sta- 
tion Paralleling and Equipment Selection. IIE Transactions, 35, 73-85. https://doi.org/10.1080/07408170304429

[14] Kasul, R.A. and Motwani, J.G. (1997) Successful Implementation of TPS in a Manufacturing Setting: A Case Study. Industrial Management and Data Systems, 97, 274-279. https://doi.org/10.1108/02635579710191707

[15] Askin, R.G. and Goldberg, J.B. (2010) A Branch-and-Bound Based Solution Approach for the Mixed-Model Work Line-Balancing Problem for Minimizing Stations and Task Duplication Costs. European Journal of Operational Research, 34, 2010-2024.

[16] Harper, S.C. and Porter, T.W. (2011) The Elusive Next Level. Institute of Industrial Engineers, September/October, 18-23.

[17] Bresnahan, T. (2010) General Purpose Technologies. In: Handbook of the Economics of Innovation, Elsevier, Amsterdam, Vol. 2, 761-791.

https://doi.org/10.1016/S0169-7218(10)02002-2

[18] Parasuraman, A., Zeithaml, V.A. and Berry, L.L. (1985) Scales for Measuring Service Quality: A Comparatives Assessment Based on Psychometric and Diagnostic Criteria. Journal of Retailing, 70, 201-230. https://doi.org/10.1016/0022-4359(94)90033-7

[19] Zeithaml, V.A. (1988) Consumer Perceptions of Price, Quality and Value: A MeansEnd Model and Synthesis of Evidence. Journal of Marketing, 52, 2-22. https://doi.org/10.1177/002224298805200302

[20] Nenadál, J. (2002) Moderní systémy rrízeníjakosti: Quality Management. 2nd Edition, Management Press, Praha. (In Czech)

[21] Garvin, D. (2007) Managing Quality: The Strategic and Competitive Edge. Free Press, New York.

[22] Gershwin, S. (2000) Design and Operation of Manufacturing Systems: The Control-Point Policy. IIE Transactions, 32, 891-906. https://doi.org/10.1080/07408170008967448

[23] Bagshaw, K.B. (2015) Lead Time Uncertainties, Average Inventory and Scheduling Practice on Manufacturing Firms in Nigeria. International Review of Management and Business Research, 4, 1118-1132.

[24] Nielsen, P., Michna, Z. and Do, N.A.D. (2014) An Empirical Investigation of Lead Time Distributions. In: Grabot, B., Vallespir, B., Gomes, S., Bouras, A. and Kiritsis, D., Eds., IFIP International Conference on Advances in Production Management Systems, Springer, Berlin, 435-442.

[25] Harrington, S.J. (1996) The Effect of Codes of Ethics and Personal Denial of Responsibility on Computer Abuse Judgments and Intentions. MIS Quarterly, 20, 257-278. https://doi.org/10.2307/249656

[26] Sarantakos, S. (2005) Social Research. 3rd Edition, Macmillan Education, Melbourne. https://doi.org/10.1007/978-0-230-20901-5

[27] Zupan, H. and Herakovic, N. (2015) Production Line Balancing with Discrete Event Simulation: A case Study. IFAC (International Federation of Automatic Control) IFAC-Papers Online, 48, 2305-2311. https://doi.org/10.1016/j.ifacol.2015.06.431

[28] Jackson, S.E. and Schuler, R.S. (1985) A Meta-Analysis and Conceptual Critique of Research on Role Ambiguity and Role Conflict in Work Settings. Organizational Behavior and Human Decision Processes, 36, 16-78.

https://doi.org/10.1016/0749-5978(85)90020-2

[29] Emiliani, M.L. (2008) Standardized Work for Executive Leadership. Leadership and Organization Development Journal, 29, 24-46. 
https://doi.org/10.1108/01437730810845289

[30] Galinsky, E., Bond, J.T., Kim, S.S., Backon, L., Brownfield, E. and Sakai, K. (2005) Overwork in America: When the Way We Work Becomes Too Much. Families and Work Institute, New York.

[31] Bagshaw, K.B. (2018) Lean Application and Efficiency of Manufacturing Firms: An Empirical Study of Manufacturing Firms in Rivers State, Nigeria. International Journal of Management Excellence, 11, 1553-1558. https://doi.org/10.17722/ijme.v11i2.466

[32] George, J.M. and Zhou, J. (2002) Understanding When Bad Moods Foster Creativity and Good Ones Don't: The Role of Context and Clarity of Feelings. Journal of Applied Psychology, 87, 687-697. https://doi.org/10.1037/0021-9010.87.4.687

[33] Löfgren, M. and Witell, L. (2008) Two Decades of Using Kano's Theory of Attractive Quality: A Literature Review. The Quality Management Journal, 15, 59-75. https://doi.org/10.1080/10686967.2008.11918056

[34] Seto-Pamies, D. (2012) Customer Loyalty to Service Providers: Examining the Role of Service Quality, Customer Satisfaction and Trust. Total Quality Management, 23, 1257-1271. https://doi.org/10.1080/14783363.2012.669551

[35] Kuhlang, P., Edtmayr, T. and Sihn, W. (2011) Methodical Approach to Increase Productivity and Reduces Lead Time in Assembly and Production-Logistic Processes. CIRP Journal of Manufacturing Science and Technology, 4, 24-32. https://doi.org/10.1016/j.cirpj.2011.02.001

[36] Tang, Y.-T. and Chang, C.-H. (2010) Impact of Role Ambiguity and Role Conflict on Employee Creativity. African Journal of Business Management, 4, 869-881. 